
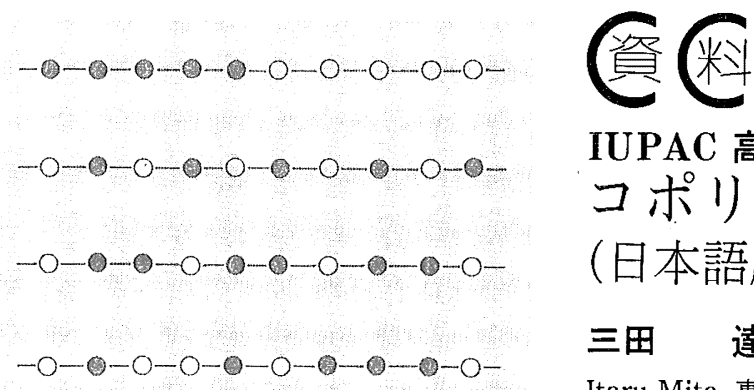

IUPAC 高分子命名法委員会による

コポリマーの原料基礎命名法 (日本語版)

\title{
三田 達
}

Itaru Mita, 東京大学工学部境界領域研究施設 - 教授

\section{日本語版の作製にあたって}

本日本語版は, IUPAC 高分子部会高分子命名法委 員会が, 1985 年に発表した "Source-Based Nomenclature for Copolymers" なる勧告1)の全訳である. この勧告は, 上記命名法委員会で 5 年以上もの長い議 論の末完成した 1983 年の未定稿に, 外部からの意見 も取り入れて最終稿としたものである.1975 年に出 された，主としてホモポリマーの命名に関する针告， “規則性単条有機ポリマーの命名法”2) が構成繰返し単 位 (CRU) の化学棈造を命名の基礎としているのに対 し，コポリマーの命名に関する本勧告では，原料化合 物を命名の基礎としている。この点に異和感を持たれ る方もあるかも知れない。しかし，同一分子種の集合 体である低分子化合物から，2次的要素とはいえ重合 度や末端基の異なる分子の混合物であるホモポリマ 一, さらに複数の CRU の配列や存在比つまり組成の 異なる分子の混合物であるコポリマーに移るにつれ， 命名法は, 分子構造との $1: 1$ の対応からしだいに分 類を示す性格のものにならざるを得ない。とすれば, コポリマーでは CRU の化学構造を指定するよりも， 原料化合物名を示す方が実質的である。それに現状で は，原料は明らかでも構造が必ずしも明確でないコポ リマーも少なくない。こうした現実的な判断がコポリ マーの命名を原料基礎方式とする根拠となった，また 本勧告では, 2 種類の違った方式の命名法を提案して いる.この点でも化合物との一義的対応という一般の 命名法の考えから逸脱している。しかしコポリマーの ような複雑な物質群すべてをカバーする命名法を樹立 するのは至難である。一つの命名法では, ある場合に は良くても他の場合には大変繁雑な名称となり実際的 でないということが起こり得る，そのため, 上記委員

Source-Based Nomenclature for Copolymers
会では，ペダンチックでなく実際に役に立つという見 地から，1つのコポりマーに2つの公的名称があるの かとの批判は甘受してあえて相補的な 2 種の命名法を 提案することになった。

高分子学会の SUN (Symbol, Unit and Nomenclature）委員会では, IUPAC の高分子関係勧告文書 のうち, 重要度の高いものは全訳し，それ以外のもの は重要度に応じ, 要約, 文書出現の紹介などを行な い, 同時に, 英語に対応する日本語の術語の確定の作 業を行なってきている、これまでに，既述の“規則性 単条有機ポリマーの命名法”2) と“ポリマーに関係あ る術語の基本的定義”3) と“高分子科学におけるモル 質量, 関連用語に関する賞書き”4)の全訳, “ポリマー に関する立体化学の定義と概念” の要約文書5)，“無機 および配位ポリマーの命名法”の出現の紹介記事(6) な どが発表されている. SUN 委員会では, 本针告“コ ポリマーの原料基礎命名法”は全訳に值する重要な文 書であると考え，1983 年より日本語術語の確定の作 業を始め, 1984 年より原文の翻訳に入り，1986 年 1 月に終了した。コポリマーの日本語名中に, $-c o-$, や-stat-のような英語記号が入ることの是非の議論 もあったが, 最終的には，やはりこの方式が最も適当 であるとの委員会全員の合意が得られた。

科学では皆の共通の基盤として一定の規則による命 名法や定義が必要なことは言うまでもないが, 他方, 言葉は生き物であって，時代に応じて動いてゆく，し たがって本命名法自身また日本語の述語についても必 ずしもすべての方に納得していただけるとは限らない ように思う。批判のあるところに進歩もある。ご意見 のある方は是非 SUN 委貝会へお知らせいただきた い。また訳文は，本文書の性格から，意識的に直訳調 として正確を期し，かなり推稿をしたつもりである が，不備な点があれば，どうぞお許しいただきたい。 


\section{SUN 委員会}

$<$ 委員長 $>$ 三田 達 (東京大学工学部)

<委 員 > 安部 明廣（東京工業大学工学部）

井上 祥平 (東京大学工学部)

今西 幸男 (京都大学工学部)

倉田 道夫 (京都大学化学研究所)

土田 英俊 (早稲田大学理工学部)

寺町 信哉 (工学院大学)

畑田 耕一 (大阪大学基礎工学部)

牧廣 (製品科学研究所)

<顧 問 $>$ 鶴田 禎二（東京理科大学工学部）

\section{文 献}

1) IUPAC Commission on Macromolecular Nomenclature: Pure and Appl. Chem., 57, 1427 (1985)

2) 鶴田禎二: 高分子, 27, 345 (1978)

3）鶴田禎二：高分子, 25, 534 (1976)

4) 三田 達: 高分子, 33, 556 (1984)

5）三田 達: 高分子, 32, 443 (1983)

6) 三田 達: 高分子, 32, 443 (1983)

注 日本語版の掲載に当たって, 日本学術会議化学研 究連絡委員長より揭載の許可を得た。
国際純正応用化学連合

(IUPAC)

高分子部会

高分子命名法委員会*

\section{コポリマーの原料基礎命名法}

(1985 年 勧告)

\section{目次}

序

基本概念

コポリマーの分類と定義

1. モノマー単位の配列が無指定のコポリマー

2. 統計コポリマー, ランダムコポリマー

3. 交互コポリマー

4. その他の周期コポリマー

5. ブロックコポリマー

6. グラフトコポリマー

7. 重縮合または関連する重合法で得られるポリマ -

8. 質量分率, モル分率, モル質量, 重合度に関す る指定

補遺：コポリマーのもう一つの命名法
W. RING (ドイツ連邦共和国), I. MITA (日本), A.D. JENKINS (連合王国), N.M. BIKALES（アメリカ合衆 国）からなる作業グループにより作成.

*本報告を準備した期間（1977～1985 年）の委員会の構 成は次の通りである。

正委員: G. A Allegra (イダリア, 1977〜1985)； R.E. Bareiss（ドイツ連邦共和国, 1983 1985）； N.M. Bikales (アメリカ合衆国, 1977 1985；書記, 1979 1985)；P. Corradini（イタリア，1968１977）；R.B. Fox（アメリカ 合衆国, 書記, 1968 1979)；A.D. Jenkins（連合王国, 1975 1985, 委員長, 1977 1985)；P. Kratochvíl（チェ コスロバキア，1979〜1985）；K.L. Loening（アメリカ合 衆国, 委貝長, 1968 1977)；I. Mita (日本, 1979 1985）；I.M. Papisov（ソビエト社会主義共和国連 邦，1979 1985）；N.A. Platé（ソビエト社会主義共和国連 邦, 1971 1983）：W. Ring（ドイツ連邦共和国, 1971 1981) ; P. Sigwalt（フランンス, 1975 1983）; U. W. Suter (スイス, 1981 1985)； T. Tsuruta (日本, 1968 1979)

準委員：N.M. Bikales（アメリ力合乑国, 1975 1977)；D. Braun（ドイツ連邦共和国，
1981 1985）；J.M.G. Cowie（連合王国，1983～1985）；L. C. Cross（連合王国, 1975 1979)； L.G. Donaruma（アメ リカ合衆国, 1977 1985)；P.B. Fox（アメリカ合䍃国, 1979 1983) ; P. Kratochvíl（チェコスロバキア, 1977 1979) ; K.L. Loening (アメリカ合衆国, 1977 1985) ; R.H. Marchessault（カナダ, 1977 1981, 1983 1985) ; I. Mita (日本, 1977 1979) ; S. Penczek (ポーランド, 1979 1983)；N.A. Platé（ソビエト社会主 義共和国連邦，1979～1983）；R.P. Quirk（アメリカ合菜 国, 1983 1985)；M. Rinaudo (フランス, 1981〜1985)； P. Sigwalt (フランス, 1983〜1985) ; L.O. Sundelof (スウ ェーデン, 1981 1983)；U.W. Suter（スイス, 1979 1981)；T. Tsuruta (日本, 1979 1983)；R.E. Wetton（連合王国, 1977 1981)；H. Wilski (ドイツ連邦 共和国, 1975 1979).

各国代表：E.M. Macchi（アルゼンチン，1983〜1985）； E.B. Mano (ブラジル, 1979 1985)；Y. Hu（中国化学 会, 1981 1983）；L. Shi（中国化学会, 1983 1985）；A. S. Tan (マレーシヤ, 1983〜1985)；G.J. Leary（ニュージ ーランド, 1981 1985)；N.A. Platé (ソビエト社会主義共 和国連邦, 1983 1985). 
序

コポリマーは科学研究, 工業的応用のいずれにおい ても著しく重要となってきた。したがって、こうした ポリマーを命名するために統一的で明確に規定された 体系は非常に有益であろう。ここで提案する命名法 は,コポリマー分子中のモノマー単位の連鎖配列 (monomeric unit sequence arrangements) の型を指 定する体系をつくりあげることによって，上記の目的 に応えようとするものである。

原則的にいえば，コポリマーを命名する総合的な構 造基礎（structure-based）の体系が望ましいであろ う。しかし，このような体系には，ポリマー分子中で のすべての構成単位の明確な構造ならびにその連鎖配 列の知識が前提として必要である。実際に手にする合 成ポリマーでこうした情報が得られることは稀であ る.この理由から本報告の提案は，本質的に原料基 礎命名法の体系 (source-based nomenclature system）を具体化したものである.

コポリマーの構造が十分に分かっていて，単条ポリ マーの諸規則（文献 1 および 2) で処理できる場合に は，本体系の適用によって構造基礎命名法の使用が抑 制されることがあってはならない。さらにIUPACIUB 生化学命名法委貝会によって公表された合成ポ リペプチドの略記命名法（文献 3) との整合性を可能 な限り維持するように努めた。本命名法の体系は, 1952 年に公表された, 前の勧告（文献 4）に優先する ものである。

\section{基本概念}

ここに提案する命名法体系は，コポリマーのために 考えられたものである. 定義によればコポリマー* は，2 種類以上の単量体からつくられたポリマーであ る(文献 5).コポリマーの種々の分類は, コポリマー 分子中のモ/マー単位の連鎖配列の特徵にもとづいて 論じられている。一般に, モノマー単位の指定には, モノマー名を用いるが, このはかモノマー単位は慣用 (trivial), 半体系的 (semi-systematic) または体系的 (systematic) 形で命名することができる.コポリマ 一の分類は, 次の通りである.

$\begin{array}{lll}\text { 無 指 定 } & \text { (unspecified) } & \text { (規則 1) } \\ \text { 統 計 } & \text { (statistical) } & \text { (規則 2.1) } \\ \text { ランダム } & \text { (random) } & \text { (規則 2.2) } \\ \text { 交 互 } & \text { (alternating) } & \text { (規則 3) }\end{array}$

*訳注 copolymerの日本語は，コポリマーと共重合体の いずれでもよい。
周 期 (periodic)

（規則 4.1）

ブロック (block)

(規則 5.1)

グラフト (graft)

(規則 6.1)

コポリマー分子が単一の連鎖配列にあるただ一種の 構成単位によって記述できる場合には，コポリマーは 規則性ポリマー (regular polymer) であり（文献 5), したがって構造基礎の方式で命名することができる (文献 1 および 2). 例は後で本文中で取り上げる.

単一のモノマーからなるが, 構成的 (constitutional) または配置的 (configurational) 特徵の異なるモノマー 単位をもつポリマーは，基本的定義（文献 5 ）に従う とコポリマーとは見做せない.このようなコポリマー でないポリマーの例は,

(a) 1,2 およ゙ 1,4 型の単位の配列が混合したポ リブタジエン

(b) 2 つのエナンチオマー $R$ と $S$ の混合物の重合 で得られ， $R$ と $S$ の単位を含むポリメチルオ キシラン, 別名ポリプロピレンオキシド.

しかし，ここで提案する命名体系は，このような擬 コポリマー (pseudo-copolymer) にも適用すること ができる、ホモポリマーから化学的変換によって誘導 される, 構成的特徵が異なるモノマー単位をもつポリ マーも同様に命名することができる。 たとえば：

（c）エステルとアルコール単位を同時にもつ部分 加水分解したポり酢酸ビニル

関係の深い別の命名法の体系を付録に示すが，場合 によってはその方がむしろ望ましい体系である.

$$
\text { コポリマーの分類と定義 }
$$

コポリマーに対する体系的な原料基礎命名法は構成 モノマーを識別し, 存在するモノマー単位の異なった 型の連鎖配列を記述するものでなくてはならない. 本 提案ではこの目的を達成するために, 接頭辞 “ポリ” の後に構成モノマーの名称を列記し, 各モノマーの組 み合わせの間に, その 2 種のモノマー単位が構造中で 結びつけられている配列の種類を示すイタリック体の 接続記号を置く，以下に 7 種の連鎖配列および対応す る接続記号と例を列挙する，A，B，Cはモノマーの 名称である。〔 $\mathrm{A}, \mathrm{B}, \mathrm{C}$ の列記の順は, 特に順序の優 位性を規則中で規定しない限り，何ら優先順位を表わ すものではない.したがって，しばしば 2 種以上の名 称が可能となる．」

それぞれの型のコポリマーは，以下でさらに詳しく 取り扱う. 末端基の化学的特徵を指示したい時には, （上記の）コポリマーの名称の前に末端基の組織名を 置く，接頭辞 $\alpha$ あるいは心は，それぞれ，構造の両 


\begin{tabular}{|c|c|c|}
\hline 型 & 接続記号*1 & 例*1 \\
\hline 無 指 定 & $-\mathrm{CO}^{-}$ & ポリ $(\mathrm{A}-\mathrm{Co}-\mathrm{B})$ \\
\hline 統 & - stat- & ポリ(A-stat-B) \\
\hline ランダム & - ran- & ポリ $(\mathrm{A}-\operatorname{ran}-\mathrm{B})$ \\
\hline 交 & -alt- & ポリ（A-alt-B) \\
\hline 周 & -per- & ポリ (A-per-B-per-C) \\
\hline ブロック & -block- & ポリ $\mathrm{A}$-block-ポリ B \\
\hline グラフト & -graft- & ポリ A-graft-ポリ B \\
\hline
\end{tabular}

端につく末端基であることを示す。

例： $\alpha-\mathrm{X}-\omega-\mathrm{Y}$-poly $(\mathrm{A}-\mathrm{co}-\mathrm{B})$

\section{1. モノマー単位の配列が無指定のコポリマー}

規則 1 モノマー単位の無指定連銷配例は $(\mathrm{A}-c o-\mathrm{B})$

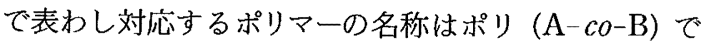
ある。

例：スチレンとメタクリル酸メチルの無指定コポリ マーの名称は

ポリ（スチレン-co-メタクリル酸メチル） poly[styrene-co-(methyl methacrylate)]

\section{2. 統計コポリマー}

統計コポリマーはモノマー単位の連鎖分布が一定の 統計的法則に従うコポリマーである。たとえばモノマ 一連鎖分布は 0 次のマルコフ統計（ベルヌーイ統計） や1次，2次またはさらに高次のマルコフ統計に従っ てもよい，速度論的にいえば，モノマー単位の統計連 鎖を与える素過程は，必ずしも同じ先験的確率で進行 するとは限らない。こうした過程によって，モノマー 単位の配列が交互性をもつ傾向，同じ単位が並ぶ傾 向，あるいは秩序的な配列傾向 (ordering tendency) を全く示さないなど各種の連鎖分布を与えることにな る(文献 6)。簡単な二成分系共重合においては，この 連鎖分布の特性は，反応性比あるいは関連する連鎖数 (run number) の関数の数值によって，示すことがで きる(文献 6,7 )。

ここで提案されている統計コポリマーなる用語は, 混合した 2 種以上のモノマーを同時に重合して得られ る広い範囲のコポリマーを指す。このようなコポリマ 一は文献中では，しばしば“ランダムコポリマー” 記述されているが，これはほとんどの場合ランダムと いj用語を不適当に使用しているので，この慣習は改 めるべきである。

規則 2.1 モノマー単位の統計連鎖配列は

\footnotetext{
*11訳注 poly は日本語でポリと書き，接続記号 $-\mathrm{CO}^{-}$, -stat-, などは英語のままで書く.
}

(A-stat-B)，(A-stat-B-stat-C) などで表わされ る。ここで-statーは $\mathrm{A} ， \mathrm{~B} ， \mathrm{C}$ 単位に関する統計連鎖 分布を示す．統計コポリマーの名称は

ポリ $(\mathrm{A}-$ stat $-\mathrm{B})$ ，ポリ $(\mathrm{A}-$ stat $-\mathrm{B}-$ stat $-\mathrm{C})$ など である。

例：ポリ(スチレン-statーブタジエン)

poly (styrene-stat-butadiene)

ポリ（スチレン-stat-アクリロニトリル-stat-

ブタジエン)

poly (styrene-stat-acrylonitrile-stat-

butadiene)

\section{ランダムコポリマー}

ランダムコポリマーは，統計コポリマーの特殊な場 合である、ランダムコポリマーは，ポリマー鎖中の任 意の部位（site）で，あるモノマー単位を見いだす確 率が，その位置の隣接単位の性質と無関係な（ベルヌ 一イ分布）統計コポリマーである，換言すると，この ようなコポリマーでは, $\mathrm{P}[\mathrm{A}], \mathrm{P}[\mathrm{B}], \mathrm{P}[\mathrm{C}]$ などを 各モノマー単位の出現する無条件確率とすると，モノ マー単位 $\mathrm{A}, \mathrm{B}, \mathrm{C}$ の連銷…ABC…を見いだす確率すな わち $\mathrm{P}[\cdots \mathrm{ABC} \cdots]$ は次式で与えられる.

$$
\mathrm{P}[\cdots \mathrm{ABC} \cdots]=\mathrm{P}[\mathrm{A}] \cdot \mathrm{P}[\mathrm{B}] \cdot \mathrm{P}[\mathrm{C}] \cdots=\prod_{i=\mathrm{A}, \mathrm{B}, \mathrm{C}, \cdots} \mathrm{P}[i]
$$

すでに述べたように “ランダム”なる用語はこの狭い 意味以外の統計コポリマーに対して，用いてはならな い*2.

一部の人は “ランダム”なる用語を，ベルヌーイ分 布でしかもモノマー単位が全く等量存在するという， さらに制約された条件の場合に用いている(文献 8).

規則 2.2 モノマー単位のランダム連鎖分布は

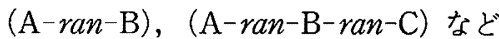
で表わされる， $\operatorname{ran}$ は A，B，Cなどの単位に関する ランダム分布を示す。ランダムコポリマーの名称は

ポリ (A-ran-B), ポリ (A-ran-B-ran-C) である。

例：ポリ (エチレンーran-䣫酸ビニル) poly [ethylene-ran-(vinyl acetate)]

\section{3. 交互コポリマー}

交互コポリマーは，交互連鎖で分布する2種のモ， マー単位を含むコポリマーである。

したがって配列

-ABABABAB-または $(\mathrm{AB})_{n}$

*2訳注 本勧告におけるランダムなる用語は，日本，ア メリカなどで一般に用いられている使い方（統 計とほとんど同じ）と非常に異なるので注意が 必要である。 
が交互コポリマーを表わす.

規則 3 モノマー単位連鎖配列は

$(\mathrm{A}-$ alt $-\mathrm{B})$

で表わされ，対応する交互コポリマーの名称は ポリ $(\mathrm{A}-$ alt-B)

である。

例：ポリ(スチレンーalt-無水マレイン酸)

poly[styrene-alt-(maleic anhydride)]

交互連鎖配列は，構成上の規則性構造 (constitutionally regular structures) をつくることが可能であ ク，その場合には, 規則性単条有機ポリマー （regular single-strand organic polymers）の構造基礎命名法 を用いて命名することができる.

上記の例の名称は，

ポリ〔(2,5-ジオキソテトラヒドロフラン -3,4-

ジイル) - (1-フェニルエチレン $)]$

poly $〔(2,5$-dioxotetrahydrofuran-3,4-diyl $)$ - (1phenylethylene)]

\section{4. そ他の周期コポリマー}

交互コポリマーのほかにモノマー単位が秩序的な連 鎖 (ordered sequence) で現われる構造が知られてい る.

たとえば：

$\begin{array}{llr}-\mathrm{ABCABCABC}- & \text { すなおち } & (\mathrm{ABC})_{n} \\ -\mathrm{ABBABBABB}- & \text { すなわち } & (\mathrm{ABB})_{n} \\ -\mathrm{AABBAABBAABB}- & \text { すなわち } & (\mathrm{AABB})_{n} \\ -\mathrm{ABACABACABAC-} & \text { すなわち } & (\mathrm{ABAC})_{n}\end{array}$

規則 4.1 モノマー単位の周期連鎖配列は

(A-per-B-per-C)

(A-per-B-per-B)

(A-per-A-per-B-per-B)

(A-per-B-per-A-per-C)

で表わされ，対応する周期コポリマ一の名称は，それ ぞれ

ポリ $(\mathrm{A}-$ per-B-per-C)

ポリ (A-per-B-per-B)

ポリ (A-per-A-per-B-per-B)

ポリ (A-per-B-per-A-per-C)

などである。

これらのポリマーが規則性であれば，規則性単条有 機ポリマーの構造基礎命名法によって命名することも できる(規則 1)。

例:

(a) フェニルホスホン酸エチレン, アクリル酸メ チルおよU゙二酸化炭素からなる三元モノマー混合物か ら，周期連鎖のコポリマー<smiles>CCCOP(=O)(CCC)CC(C(=O)O)C(=O)OC</smiles>

を得ることが可能であり，その名称は ホポリ(フェニルホスホン酸エチレン-per-

アクリル酸メチル-per-二酸化炭素)

poly [(ethylene phenylphosphonite)-per-

(methyl acrylate)-per-(carbon dioxide)] である。

\section{構造基礎名は}

ポリ〔オキシエチレンオキシ(フェニルホスホノイ ル)-2-メトキシカルボニル-3-オキソトリメチレ ン]

poly〔oxyethyleneoxy (phenylphosphonoyl)

(2-methoxycarbonyl)-3-oxotrimethylene)] である。

(b) ホルムアルデヒドとエチレンオキシドからな る二元モノマー混合物は, 周期的順列のコポリマー $\left.+\mathrm{CH}_{2}-\mathrm{O}-\mathrm{CH}_{2}-\mathrm{CH}_{2}-\mathrm{O}-\mathrm{CH}_{2}-\mathrm{CH}_{2}-\mathrm{O}\right)_{n}$ を与えるかもしれないい，その名称は

ポリ(ホルムアルデヒド-per-エチレンオキシドperーエチレンオキシド)

poly〔formaldehyde-per-(ethylene oxide)per-(ethylene oxide)]

または，

ポリ(ホルムアルデヒド-alt-ビス

エチレンオキシド)

poly [formaldehyde-alt-bis (ethylene oxide)]

または，別名として，

ポリ(オキシメチレンオキシエチレンオキシ

エチレン)

poly (oxymethyleneoxyethyleneoxyethylene) である。

規則 4.2 コポリマーの構造に何種かの周期的な位置 があり，そのいくつかのみを常に特定の種類のモノマ 一単位 $(A, B, \cdots)$ が占め, 他の位置を 2 種以上の モノマ一単位 (U, V, ․) が不規則な順序で占める とすると, 後者の位置のモノマ一の名称は, 括弧の中 に入れたセミコロンで分けて示す.

例:

(a) 次の連鎖配列

-AUAVAVAUAVAUAU-

のコポリマーの名称は

ポリ〔A-alt- $(\mathrm{U} ; \mathrm{V})]$

である。 
(b) 次の連鎖配列

-AUBUAVBUAVBVAUBVAUBU-

のコポリマーの名称は

ポリ (A-per-(U；V)-per-B-per- $(\mathrm{U} ; \mathrm{V})\rfloor$

である。

\section{5. ブロックコポリマー}

ブロックポリマーは複数のブロックが線状に配列し た分子からなるポリマーであり，ブロックとはポリマ 一分子の一部分でそのモノマー単位か隣接する部分に は存在しない，構成上あるいは配置上の特徵を少なく とも一つもつものである(文献 5).ブロックコポリマ 一は構成上の特徵に違いがある，すなわち，各ブロッ クは別種のモノマーから誘導された単位をもつ。 以下の連鎖配列

-AAAAAAAA-BBBBBBBBBBB-AAAAAAAABBBBBBBBBBB-AAAAAAAA-

AABABAAABB-AAAAAAAABBBBBBBBBBB-

で連鎖 - AAAAAAAA-，-BBBBBBBBBBB-およ び-AABABAAABB-がブロックである。

規則 5.1 ブロックの連鎖配列は

$\mathrm{A}_{\mathrm{k}}-$ block $-\mathrm{B}_{\mathrm{m}}$

$\mathrm{A}_{\mathrm{k}}$-block-(A-stat $\left.-\mathrm{B}\right)$

などで表わされ，対応するポリマーの名称は，各々 ポリ A-block-ポリ B

ポリ $\mathrm{A}-$ block-ポリ (A-stat-B)

などである。もし混乱が起こらなければ，ブロック結 合を示すのに次式のような長いダッシュを用いてもよ い.

ポリ $\mathrm{A}$ 一ー゚゚リ $\mathrm{B}$

複雑な場合には，長いダッシュよりも blockを用い ることが望ましい，各ブロックの名称を並べる順は左 から右へ書いて鎖の中のブロックの続く順に対応させ る。

例：以下の例で下ツキ $\mathrm{k}, \mathrm{m}, \cdots$ 业不定数でも特定 の值でもよい（規則 5.3 参照）。いずれの場合にも， 第 1 行はブロック連鎖配列の表示であり，第 2 行は対 応する名称，第 3 行は特定の場合の例示である。

$\mathrm{A}_{\mathrm{k}}-$ block $-\mathrm{B}_{\mathrm{m}}$

ポリ $\mathrm{A}-$ block-ポリ $\mathrm{B}$

ポリスチレンーblock-ポリブタジエン

polystyrene-block-polybutadiene

$\mathrm{A}_{\mathrm{k}}-$ block $-\mathrm{B}_{\mathrm{m}}-$ block $-\mathrm{A}_{\mathrm{k}}$ ポリ A-block-ポリ B-block-ポリ A

ポリスチレン-block-ポリブタジエンーblock-

高分子 35 巻 9 月号（1986 年）
ポリスチレン

polystyrene-block-polybutadiene-blockpolystyrene

$(\mathrm{A}-$ stat $-\mathrm{B})-$ block $-\mathrm{A}_{\mathrm{k}}-$ block $-\mathrm{B}_{\mathrm{m}}$ ポリ (A-stat $-\mathrm{B})-$ block-ポリ A-block-ポリ B ポリ(スチレン-stat-ブタジエン)-block-ポリ

スチレンーblock-ポリブタジエン

poly (styrene-stat-butadiene)-block-

polystyrene-block-polybutadiene

$\mathrm{A}_{\mathrm{k}}-$ block $-\mathrm{B}_{\mathrm{n}}-$ block $-\mathrm{C}_{\mathrm{m}}$ ポリA-blockーポリB-blockーポリC

ポリスチレンーblock-ポリブタジエンーblock-ポ

リメタクリル酸メチル

polystyrene - block - polybutadiene - block - poly (methyl methacrylate)

規則 5.2 たとえば

$-\mathrm{A}_{\mathrm{k}}-\mathrm{B}_{\mathrm{n}}-\mathrm{C}_{\mathrm{m}}-$

のようなブロックが連続する場合，適切な倍数接頭辞 を用いる。

例: $\left(\mathrm{A}_{\mathrm{k}}-\text { block }-\mathrm{B}_{\mathrm{n}}-\text { block }-\mathrm{C}_{\mathrm{m}}\right)_{3}$ トリス (ポリ A-block-ポリ B-blockーポリ C)

$\left(\mathrm{A}_{\mathrm{k}}-\text { block }-\mathrm{B}_{\mathrm{n}}-\text { block }-\mathrm{C}_{\mathrm{m}}\right)_{\mathrm{p}}$ ポリ (ポリ A-blockーポリ B-block-ポリC)

規則 5.3 ブロックの鎖長を特定できる時には，ポリ を用いるより適切なギリシャ語系接頭辞（たとえば 100 に対しへクタ）を用いる．短い連鎖長のものは厳 密には“ブロック”の定義の範囲外であるが，一般的 な接頭辞オリゴもしくは適切な特定の接頭辞（たと之 ばトリ）を用いて同じ表現とすることができる。

例： $\mathrm{A}_{\mathrm{c}}-$ block $-\mathrm{B}_{8}$ オリゴA-block-オクタ $\mathrm{B}$

$\left(\mathrm{A}_{\mathrm{c}}-\text { block }-\mathrm{B}_{\mathrm{k}}-\text { block }-\mathrm{C}_{3}\right)_{n}$

ポリ（オリゴA-blockーポリ B-block-ポリC)

$\left(\mathrm{A}_{\mathrm{c}}-\text { block }-\mathrm{B}_{\mathrm{k}}\right)_{4}$

テトラキス（オリゴA-blockーポリ B)

上記 C はオリゴマー連鎖の重合度に対応する小さ な整数である。

規則 5.43 種類以上のモノマーからつくられ，さら にブロック自身が統計連鎖配列を示すブロックポリマ 一は規則 2.1 の原理に従って命名する.

例：統計連鎖配列

$-\mathrm{A}_{\mathrm{k}}-$ block $-\mathrm{B}_{\mathrm{m}}-$ block $-\mathrm{C}_{\mathrm{n}}-$ block $-\mathrm{B}_{\mathrm{m}}-$ block -

$\mathrm{A}_{\mathrm{k}}-$ block $-\mathrm{C}_{\mathrm{n}}-$

の名称は

ポリ（ポリA-stat-ポリB-stat-ポリC) 
である。

規則 5.5 複数のブロックが，ブロックの一部でない 接合単位 X によって結合しているブロックコポリマ 一の名称では, 接合単位の名称を適切な位置に挿入す る。接合記号-block-は省略してもよい.したがって, $-\mathrm{A}_{\mathrm{k}}-$ block $-\mathrm{X}-$ block $-\mathrm{C}_{\mathrm{m}}-$

または

$$
-\mathrm{A}_{\mathrm{k}}-\mathrm{X}-\mathrm{C}_{\mathrm{m}}-
$$

の名称は, ーポリ A-block-X-block-ポリC-

または

ーポリ $\mathrm{A}-\mathrm{X}$ ーポリC-

である。同様の表現がブロックポリマーにも適用でき る.

例：ポリスチレンーblock-ジメチルシリレンー block-ポリブタジエン

polystyrene-block-dimethylsilylene-blockpolybutadiene

あるいは， ポリスチレンージメチルシリレンーポリブタジエン polystyrene-dimethylsilylene-polybutadiene ポリスチレン-block-ジメチルシリレンーblockポリスチレン

polystyrene-block-dimethylsilylene-blockpolystyrene

あるいは

ポリスチレンージメチルシリレンーポリスチレン polystyrene-dimethylsilylene-polystyrene

規則 5.6 ポリマー分子中で接合基 $\mathrm{X}$ を通じて結ば れた $\mathrm{A}_{\mathrm{k}}$ ブロックと $\mathrm{B}_{\mathrm{m}}$ ブロックが

$-\mathrm{A}_{\mathrm{k}}$-block $-\mathrm{X}-$ block $-\mathrm{B}_{\mathrm{m}}-$ block $-\mathrm{X}-$

block $-\mathrm{B}_{\mathrm{m}}-$ block $-\mathrm{X}-$ block $-\mathrm{A}_{\mathrm{k}}-$

のように統計的に分布しているブロックコポリマーの 名称は,

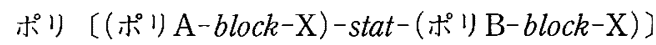
である。

$\mathrm{A}_{\mathrm{k}}$ ブロックと $\mathrm{B}_{\mathrm{m}}$ ブロックと接合単位 $\mathrm{X}$ が

$-\mathrm{A}_{\mathrm{k}}$-block $-\mathrm{X}-$ block $-\mathrm{B}_{\mathrm{m}}-$ block $-\mathrm{A}_{\mathrm{k}}$-block-

$\mathrm{B}_{\mathrm{m}}$-block-X-block $-\mathrm{B}_{\mathrm{m}}-$ block $-\mathrm{X}-$

block- $\mathrm{A}_{\mathrm{k}}-$

のようにすべて統計的に分布しているブロックコポリ マ一の名称は,

ポリ (ポリA-stat-X-statーポリB)

である。

\section{6. グラフトコポリマー}

グラフトポリマーは，側鎖として主鎖に結合した 1 個または複数個のブロックがあり，しかもこれらの側 鎖が主鎖とは異なる構成上または配置上の特徵をもつ 分子からなるポリマーである(文献 5)。グラフトコポ リマーでは，側鎖は構成上異なる特徵をもつ，すなわ ち，側鎖に含まれる単位の少なくとも 1 つは，主鎖の 単位を与えるモノマーと異なる種類のモノマーから得 られるものである。

規則 6.1 グラフトコポリマーの最も簡単な場合は

$\mathrm{A}_{\mathrm{k}}-$ graft $-\mathrm{B}_{\mathrm{m}}$

もしくは

-AAAAAAAA X AAAAAAAA-

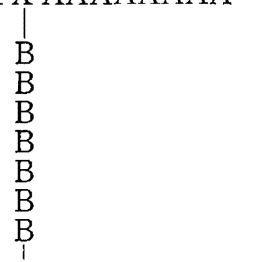

で表わされ，対応する名称は，

ポリA-graftーポリ B

である、はじめに名称を示すモノマー(この場合 A) は幹（主鎖）の単位を与之るモノマーであり，次に名 称を示すモノマー（B）は枝（側鎖）にあるものであ る.

例：以下の各例は，それぞれグラフト連鎖配列，対 応する名称および特定の場合の例示である。

(a)

$\mathrm{A}_{\mathrm{k}}-$ graft $-\mathrm{B}_{\mathrm{m}}$ ポリA-graftーポリ B

ポリブタジエンーgraftーポリスチレン

polybutadiene-graft-polystyrene

(ポリスチレンがグラフトしたポリブタジエン）

(b)

$\left(\mathrm{A}_{\mathrm{k}}-\right.$ block $\left.-\mathrm{B}_{\mathrm{m}}\right)-$ graft $-\mathrm{C}_{\mathrm{n}}$ (ポリA-blockーポリ B)-graftーポリC

(ポリブタジエンーblockーポリスチレン)graft-ポリアクリロニトリル

(polybutadiene-block-polystyrene)graft-polyacrylonitrile

（無指定の位置にポリアクリロニトリルがグラワトし たポリブタジエンーblockーポリスチレン)

(c)

$$
\begin{aligned}
& \text { (A-stat-B)-graft- } \mathrm{C}_{\mathrm{m}} \\
& \text { ポリ }(\mathrm{A}-\text { stat }-\mathrm{B})-\text { graft-ポリC } \\
& \text { ポリ(ブタジエン-stat-スチレン)- }
\end{aligned}
$$


graft-ポリアクリロニトリル

poly (butadiene-stat-styrene)-graft-

polyacrylonitrile

(ポリアクリロニトリルが，無指定位置でグラフト したポリ(ブタジエン-stat-ポリスチレン))

(d)

$\mathrm{A}_{\mathrm{k}}-$ block- $\left(\mathrm{B}_{\mathrm{m}}-\right.$ graft $\left.-\mathrm{C}_{\mathrm{n}}\right)$

ポリ A-blockー(ポリB-graftーポリC)

または

(ポリB-graftーポリC)-block-ポリA

ポリブタジエンーblockー(ポリスチレンー

graftーポリアクリロニトリル)

または

(ポリスチレン-graftーポリアクリロニトリ

ル)-blockーポリブタジエン

(polystyrene - graft - polyacrylonitrile)block-polybutadiene

(ポリスチレンブロックにポリアクリロニトリルがグ ラフトしたポリスチレン-blockーポリブタジェン)

(e)

$\left[\mathrm{A}_{\mathrm{k}}-\right.$ graft- $\left.(\mathrm{B}-\mathrm{co}-\mathrm{C})\right]-$ block $-\mathrm{B}_{\mathrm{m}}$

[ポりA-graftーポリ (B-co-C)]-blockーポリ B

あるいは

ポリ B-blockー[ポリA-graftーポリ（B-co-C)]

〔ポリブタジエン-graftーポリ(スチレンーco-

アクリロニトリル)]-block-ポリスチレ

(polybutadiene-graft-poly (styrene-co-

acrylonitrile)]-block-polystyrene

ポリスチレンーblock-〔ポリブタジエン-graft-

ポリ(スチレンーco-アクリロニトリル)

polystyrene - block - (polybutadiene - graft - poly

(styrene-co-acrylonitrile)]

(ポリ(スチレンーcoーアクリロニトリル) がポリブタジ エンブロックにグラフトした，ポリスチレン-blockポリブタジエン)

規則 6.2 幹に， 2 種以上のグラフト鎖が結合してい る場合には，グラフトの名称またはその表示記号を分 離するのにセミコロンを用いる。

例： $A_{k}-g r a f t-\left(B_{m} ; C_{n}\right)$

ポリA-graftー(ポリB；ポリC)

ポリブタジエン-graft-(ポリスチレン；ポリメ

タクリル酸メチル)

polybutadiene - graft - (polystyrene ; poly -

(methyl methacrylate))

(ポリスチレンおよU゙ポリメタクリル酸メチル鎖がグ ラフトしたポリブタジエン)
規則 6.3 グラフト鎖の数が分かっているグラフ.トコ ポリマーは，数接頭辞（モノ，ビス，トリス，等々） を用いて命名する。

例: $\mathrm{A}_{\mathrm{k}}-\left(- \text { graft- } \mathrm{B}_{\mathrm{m}}\right)_{3}$ ポリAートリス (-graft-ポリB) ポリブタジエンートリス(-graftーポリスチレン) polybutadiene-tris (-graft-polystyrene)

(ポリブタジエン幹あたり 3 本のポリスチレンのグラ フト)

もしグラフトの正確な部位が分かればそれを指定す ることができる.

例 : $\mathrm{A}_{10}-$ block- $\left(\mathrm{X}\right.$-graft $\left.-\mathrm{B}_{\mathrm{m}}\right)-$ block- $\mathrm{A}_{15}$ デカ A-block-(X-graft-ポリ B )-block-

ペンタデカA

デカブタジエン-block-(メチルシラントリイルー graft-ポリスチレン)-block-ペンタデカブタ ジエン)

decabutadiene-block-(methylsilanetriylgraft-polystyrene) - blockpentadecabutadiene

グラフトコポリマーの命名体系は, 原則として, 構 成上または配置上特徵の異なる鎖が中心の接合基によ って結合している“星型コポリマー”にも適用できる。 例:

(a)

$$
\left.\mathrm{A}_{\mathrm{k}}-\text { block-[X }\left(- \text { graft }-\mathrm{B}_{\mathrm{m}}\right)_{2}\right]- \text { block }-\mathrm{A}_{\mathrm{k}}
$$
または，

$\mathrm{B}_{\mathrm{m}}-$ block-[X $\left.\left(- \text { graft }-\mathrm{A}_{\mathrm{k}}\right)_{2}\right]-$ block $-\mathrm{B}_{\mathrm{m}}-$ ポリ $\mathrm{A}-$ block-[X-ビス (-graft-ポリ $\mathrm{B})]-$ blockーポリA

または，

ポリ B-block-[X-ビス (-graft-ポリ A)]blockーポリ B

ポリスチレンーblock-〔シランテトライルービ ス(-graftーポリブタジエン)]-block-ポリ スチレン

polystyrene-block-[silanetetrayl-bis (- graft-polybutadiene) )-blockpolystyrene

または、

ポリブタジエンーblock-〔シランテトライルー

ビス (-graftーポリスチレン)]-blockーポリ ブタジエン

polybutadiene-block-〔silanetetralyl-bis (graft-polystyrene)]-block-polybutadiene (中心の Si 原子にポリスチレン鎖 2 本, ポリブタジエ ン鎖 2 本が結合したもの) 
(b)

$\mathrm{A}_{\mathrm{k}}-$ block-[X-graft $\left.-\left(\mathrm{B}_{\mathrm{m}} ; \mathrm{C}_{\mathrm{n}}\right)\right]-$ block $-\mathrm{D}_{\mathrm{p}}$ ポリ A-block-[X-graft-(ポリ $\mathrm{B}$; ポリ $\mathrm{C})]-$ block-ポリD

ポリスチレンーblockー〔シランテトライルー graft-(ポリブタジエン；ポリイソプレ ン)]-block-ポリ(メタクリル酸メチル)

polystyrene - block - [silanetetrayl - graft (polybutadiene ; polyisoprene)]-block poly (methyl methacrylate)

(中心の Si 原子に, ポリブタジエン鎖, ポリイソプレ ン鎖，ポリスチレン鎖，ポリメタクリル酸メチル鎖の 結合したもの)

何を優先するかの規則はないので，いくつかの他の 名称が可能である.

\section{7. 重縮合または関連する重合法で 得られるポリマー}

コポリマーの命名法の体系は，一種以上のモノマー を用いた重縮合，または一般的にいかなる大きさの分 子（すなわちモ/マー,オリゴマー，ポリマー）でも 互いに反応しjる重合，で得られるポリマーにも適用 できる。この場合, 単独重合し得るモノマーの重縮合 で得られるポリマーの場合と, 通常別々には単独重合 しない相補的な成分の重縮合で得られるポリマーの場 合とを区別することができる.

コポリマーの原料基礎方式の定義（文献 5) を厳密 に適用すると，(通常ホモポリマーと見做されている） ポリエチレンテレフタラートあるいはポリへキサメチ レンアジパミドは，それぞれ 2 種の成分が重合の普通 の出発物質であるから，コポリマーに含まれる。この 種のポリマーが構成上規則的な構造をもち，規則性ポ リマーであれば, 規則性単条有機ポリマーの命名法も 用いることができる(文献 1). 以上のことを例之ばテ レフタル酸とエチレングリコールから得られるポリマ 一に適用すると，もしこのポリマーが事実テレフタル 酸とエチレングリコールから出発し, 重縮合で得られ たものであれば，その名称は原料基礎コポリマー命名 法により

ポリ（エチレングリコール-alt-テレフタル酸）

poly (ethylene glycol-alt-terephthalic acid) となろう。しかし, もし出発物質が部分エステル

\section{$\mathrm{HOCH}_{2} \mathrm{CH}_{2} \mathrm{OCOC}_{6} \mathrm{H}_{4} \mathrm{COOH}$}

であれば，对応する原料基礎名は，ホモポリマーの名 称であるし，他方，出発物質として(工業的に広く用い られている)ビス(ヒドロキシエチル)テレフタラート

$\mathrm{HOCH}_{2} \mathrm{CH}_{2} \mathrm{OCOC}_{6} \mathrm{H}_{4} \mathrm{COOCH}_{2} \mathrm{CH}_{2} \mathrm{OH}$
が用いられれば，その名称は

ポリ（ビスヒドロキシエチルテレフタラート）

poly [bis (hydroxyethyl) terephthalate]

が提唱されよう. 用いた出発物質いかんにかかわら ず, 棈造基礎名は,

ポリ(オキシエチレンオキシテレフタロイル)

poly (oxyethyleneoxyterephthaloyl)

である、ポリエチレンテレフタラートという慣用名 も, 文献で広く確立されているので, 認めて良かろ i.

$2 つ の$ 相補的な二官能性の成分（つまりモノマー） の重縮合において，両成分が容易に $1: 1$ で反応して 潜在的モノマー (implicit monomer), つまりその単 独重合で実際の生成物を与えるはずのモノマーを与之 るように見之る場合，この重合で得られるすべてのポ リマーについて，それが規則的で, 単一の構成繰返し 単位をもつものとして表現できる限り，単条の構造基 礎命名法が適していよう．注意すべきことは，この命

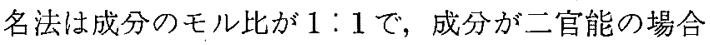
に限り適用できるという点である。

上記の反応系に第三成分を導入すると，下記の例の ように既に述べた諸規則から論理的に展開できるコポ リマーの命名法を用いる必要がでてくる。テレフタル 酸とイソフタル酸の混合物とエチレングリコールとの 反応で得られるコポリマーの名称は，

ポり〔(エチレングリコールーalt-テレフタル酸) $c o-($ エチレングリコール-alt-イソフタル酸)] poly〔(ethylene glycol-alt-terephthalic acid)co-(ethylene glycol-alt-isophthalic acid)] ポリ (エチレンテレフタラートーco-エチレンイソフ タラート)

poly (ethylene terephthalate-co-ethylene isophthalate)

または，

ポリ〔(エチレングリコール)-alt-(テレフタル酸； イソフタル酸)]

poly〔(ethylene glycol)-alt-(terephthalic acid : isophthalic acid)]

である。

トリメチロールプロパンの存在下で，オリゴ（アジ ピン酸-alt-1,4-ブタンジオール)とオリゴ(2,4-トル エンジイソシアナートーco-トリメチロールプロパン) から得られるコポリマーの名称は

ポリ〔オリゴ(アジピン酸-alt-1, 4-ブタンジオール) co-オリゴ(2,4-トルエンジイソシアナート-co-ト リメチロールブロパン)ーco-トリメチロールプロ パン] 
poly $〔$ ligo (adipic acid-alt-1,4-butanediol)co-oligo (2,4-toluene diisocyanate- ${ }^{-} o^{-}$ trimethylolpropane)-co-trimethylolpropane] である。

$2 つ の$ 相補的官能基を分子の両端にもつ真のモノマ 一(例之ば 6-アミノへキサン酸) の単独の重縮合で得 られるポリマーは，定義に従って（規則的）ホモポリ マーである。この夕イプの 2 種類のモ/マーが互いに 反応した時の生成物はコポリマーであり，適当な方式 によって命名することができる。例之ば，もし6-ア ミノへキサン酸と7-アミノヘプタン酸とをモノマー 単位が統計的に分布する共重合を行なわせると，生成 物の名称は,

ポリ〔(6-アミノへキサン酸) -stat-(7-アミ)

ヘプタン酸 $)]$

poly〔(6-aminohexanoic acid $)-$ stat- $-\left(7-\right.$ amino $^{-}$

heptanoic acid)]

である。

\section{8. 質量分率，モル分率，モル質量*, 重合度に関する指定}

モノマーまたはブロックの直後の下ツキ数字で重合 度または繰返し数を表わすのに対し，質量分率 (mass fraction)，モル分率およびモル質量（molar mass)一ほとんどの場合平均值である一は，コポリマ 一の完全な名称または記号の後に対応する数字を記載 して表現できよう。列記の順序はコポリマーの名称ま たは記号中のモノマー種の順序と同じである。未確定 の数值は $\mathrm{a}, \mathrm{b}$ などで示すことができる.

この方式は複雑な場合にも拡張できるが, 簡単な場 合にのみ適用することが望ましい。ささらに複雑な系の 取り扱いは，文章中で説明すべきである。

規則 8.1 モノマー単位の質量分率，または質量百分 率はコポリマーの名称の後の括弧の中に置き，その後 にそれぞれ“w”の記号または “質量\% (mass \%)”の 用語を書く。括弧の中の列記の順序は名称中の順序と 同じである。

例：(a)

$$
\begin{aligned}
& \text { ポリブタジエン-graft-ポリスチレン } \\
& (0.75: 0.25 \mathrm{w})
\end{aligned}
$$

または

ポリブタジエン-graft-ポリスチレン

(75：25 質量\%)

(ポリブタジエン 75 質量\% とグラフトしたポリスチ

\footnotetext{
*訳注 モル質量でなく，単位のない分子量を用いる方が 便利である。
}

レン 25 質量\% を含むグラフトコポリマー）

(b)

ポリブタジエン-graftーポリ（スチレンーstat-

アクリロニトリル)

$(0.75: \mathrm{a}: \mathrm{b} w)$

または，

ポリブタジエン-graft-ポリ（スチレン-stat-

アクリロニトリル)

(75: $\mathrm{a}: \mathrm{b}$ 質量\%)

規則 8.2 モノマー単位のモル分率またはモル百分率 はコポリマーの名称の後の括弧中に置き，その後にそ れぞれ “的”の記号または“モル\%”の用語を書く。括 弧の中の列記の順は，名称中の順序と同じである。

例：ポリブタジエン-graft-ポリスチレン

$$
(0.85: 0.15 \mathrm{x})
$$

または

ポリブタジエン-graft-ポリスチレン

(85: 15 モル\%)

(ブタジエン単位 85 モル\% とスチレン単位 15 モル\% を含むグラフトコポリマー)

規則 8.3 モ儿質量, 相対分子質量, 重合度は, 対応 する数字を加え，その後にそれぞれ，記号 $M, M_{\mathrm{r}}$ ま たは DPを書くことにより規則 8.1 と 8.2 の方式に含 めることができよう。

例：ポリブタジエン-graftーポリスチレン

$\left(75 ： 25\right.$ 質量\%；90000：30000 $M_{\mathrm{r}}$ )

（主鎖として相対分子質量 90000 のブタジエン単位 75 質量\%と相対分子質量 30000 のグラフト鎖のスチレン 単位 25 質量\% を含むグラフトコポリマー)

ポリブタジエンーgraftーポリスチレン

(1700:290 DP)

(重合度 290 のポリスチレンがグラフトした重合度 1700 のポリブタジエン主鎖からなるグラフトコポリ マ-)

\section{補遺：コポリマーのもうーつの命名法}

本報告の主文に展開したコポリマーの命名法の体系 は，いかに複雑な構造のコポリマーに対しても組織的 な名称を与えるという要求に応えるように設計されて いる，その結果，組織名は場合によって望ましくない ほど長いことも起こる。しかし，文献に現われる多く のコポリマーは比較的簡単な構造をもち，こうした精 緻な体系の必要がない。こうした簡単な場合のため, ここでは他のはるかに簡潔な命名法の体系を別法とし て示す。 


\section{基本原理}

このもう一つの命名法の体系は次の諸原理よりな る.

(i) コポリマーは接頭辞“コポリ”の後に用いる モノマーの名称（原料基礎名）を列記して表わす。こ の接頭辞はただ 1 回だけ用いる。その点では規則性単 条ポリマー（以下では規則性ポリマーと呼ぶ）(文献 1) または主文中の簡単なコポリマーの命名法で“ポリ” という接頭辞がただ 1 回用いられるのと同様である.

例：コポリ（スチレン/ブタジエン）

copoly (styrene/butadiene)

(ii）コポリマー中の構造の種類の指定（主文中の 命名法の体系におけるblock, alt などの接頭辞) は“コ ポリ”の前にイタリック字体の接頭辞で示す.

例：block-コポリ(スチレン/ブタジエン)

block-copoly (styrene/butadiene)

(iii）コポリマーの名称の主要部にはモノマーの名 称のみが含まれる、末端単位は, 主要名称の前に接頭 辞 $\alpha$ およびゅを用いて指示し, 各ブロック間の接続 単位は主要名称の後に（記号 $\mu$ を用いて）指示する.

例：block-コポリ(スチレン/ブタジエン)- $\mu^{-}$

ジメチルシリレン

block-copoly (styrene/butadiene) - $\mu^{-}$ dimethylsilyene

（iv）コポリマー中のモノマー単位の質量分率，モ ル分率, モル質量, 重合度は名称と分けて名称の後に 括弧中に指示する.

（v） 構造が単一の方法では分類できないようなよ り複雑なコポリマーに対しては，上記（i）（iv）で 述べた原理に加えて,さらにいくつかの規約を設け る.

一般にモノマ一名の列記の順序については，何を優 先するかの規則は設けない.しかしブロックあるいは 周期コポリマーにおいては，モノマー名の列記の順序 は，その分子中でモノマー単位が並ぶ順序に対応させ る.グラフトコポリマーでは，はじめに書く名称が幹 骨格 (主鎖) モノマーの名称である。

\section{A.1 簡単なコポリマーへの適用}

以下に示す例では，本報告の主文にある精緻な体系 にもとづく名称を，本補遺で提案した別名の後に与え てある。

規則 A.1.1 コポリマーの名称は, コポリ (A/B), コポリ $(\mathrm{A} / \mathrm{B} / \mathrm{C})$ ，等々のように接頭辞“コポリ”と， その後の括弧中に使用されるモノマ一の名称を，斜線 で分離して列記したものからなる，上記中 $\mathrm{A}, \mathrm{B}, \mathrm{C}$
は用いるモノマーの名称である。

例：コポリ(スチレン/メタクリル酸メチル)

copoly (styrene/methyl methacrylate) 主文の名称

ポリ(スチレンーco-メタクリル酸メチ

ル)

poly (styrene- $\mathrm{co}^{-}$methyl methacylate)

規則 A.1.2 コポリマー中のモノマー単位の配列が明 らかな場合には, 以下のイタリック字体の接頭辞のい ずれかで指示する，stat(統計), $\operatorname{ran}$ (ランダム), alt (交互), per(周期), block(ブロック), graft(グラフ ト）(主文中のコポリマーの分類と定義を参照)

例:

stat-コポリ(スチレン/ブタジエン)

stat-copoly (styrene/butadiene)

ポリ(スチレンーstatーブタジエン)

poly (styrene-stat-butadiene)

ran-コポリ（エチレン/酶酸ビニル)

ran-copoly (ethylene/vinyl acetate)

ポリ (エチレンーran-酢酸ビニル)

poly (ethylene-ran-vinyl acetate)

altーコポリ(スチレン/無水マレイン酸)

alt-copoly (styrene/maleic anhydride)

ポリ(スチレンーalt-無水マレイン酸)

poly (styrene-alt-maleic anhydride)

perーコポリ(フェニルホスホン酸エチレン/アクリ

ル酸メチル/二酸化炭素)

per-copoly (ethylene phenylphosphonite/methyl acrylate/carbon dioxide)

ポリ(フェニルホスホン酸エチレンー

per-アクリル酸メチル-per-

二酸化炭素)

poly ( (ethylene phenylphosphonite) -

per-(methyl acrylate)-per-

(carbon dioxide)]

block-コポリ(スチレン/ブタジエン/メタクリル酸 メチル)

block-copoly (styrene/butadiene/methyl methacrylate)

ポリスチレンーblock-ポリブタジエンー

block-ポリメタクル酸メチル

polystyrene-block-polybutadiene-

block-poly (methy methacrylate)

graft-コポリ(ブタジエン/スチレン)

graft-copoly(butadiene/styrene) 
ポリブタジエン-graft-ポリスチレン

polybutadiene-graft-polystyrene

規則 A.1.3 特定のモノマー単位が周期コポリマー中 でまとまって現われる時には，これを“ポリキス”型 接頭辞で示すことができる、ブロックコポリマー中の ブロックの組の繰返しが一定数または数が分からなく とも何回かある場合も同様に表わすことができる。 例：

$$
\begin{gathered}
\text { per-コポリ }(\mathrm{A} / \mathrm{B} / \mathrm{B} / \mathrm{B})=\text { per-コポリ }(\mathrm{A} / \\
\text { トリス } \mathrm{B})=a \text { alt-コポリ }(\mathrm{A} / \text { リス } \mathrm{B}) \\
\text { ポリ }(\mathrm{A}-\text { per-トリス } \mathrm{B})
\end{gathered}
$$$$
\text { block-コポリ }(\mathrm{A} / \mathrm{B} / \mathrm{C} / \mathrm{A} / \mathrm{B} / \mathrm{C} / \mathrm{A} / \mathrm{B} / \mathrm{C})=
$$$$
\text { blockーコポリ〔トリス }(\mathrm{A} / \mathrm{B} / \mathrm{C})]
$$

トリス(ポリ A-block-ポリ B-block-ポリC)

$$
\text { per-コポリ〔ホルムアルデヒド/ビス(エチレンオ }
$$$$
\text { キシド)\} }
$$$$
\text { per-copoly [formaldehyde/bis (ethylene oxide)] }
$$$$
\text { ポリ〔ホルムアルデヒド-per-ビス(エ }
$$$$
\text { チレンオキシド)] }
$$

poly〔formaldehyde-per-bis (ethylene oxide)]

規則 A.1.4 本来，交互または周期コポリマーで，そ の 1 種類の部位 (site) が（主文の規則 4.2 で述べたコ ポリマー中のように) 2 種以上のモノマーから誘導さ れる単位で占められる時, このポリマーの名称は主文 の原理およびこの補遺中の規則にもとづいて示され る。

例:

$$
\begin{aligned}
& \text { per-コポリ }(\mathrm{A} / \mathrm{B} /(\mathrm{C} ; \mathrm{D})) \\
& \text { ポリ (A-per-B-per (C ; D ) }] \\
& \text { alt-コポリ〔メタクリル酸メチル/(スチレン； } \\
& \text { 1-ビニルナフタレン)] } \\
& \text { alt-copoly (methyl methacrylate/(styrene ; } \\
& \text { 1-vinylnaphthalene)] } \\
& \text { poly〔メタクリル酸メチル-alt-(スチレ } \\
& \text { ン；1-ビニルナフタレン)] } \\
& \text { poly (methyl methacrylate-alt- } \\
& \text { (styrene ; 1-vinylnaphthalene)] }
\end{aligned}
$$

1 つの幹骨格 (A)に2 種以上の種類の枝 (B，Cなど) がグラフトしたグラフトコポリマーの命名にも，同じ 手法が用いられる。

例 :

$$
\begin{aligned}
& \text { graft-コポリ〔A/(B；C)〕 } \\
& \text { ポリA-graft-(ポリ B；ポリC) } \\
& \text { graft-コポリ〔ブタジエン/(スチレン； } \\
& \text { 高分子 } 35 \text { 巻 } 9 \text { 月号 （1986 年） }
\end{aligned}
$$

メタクリル酸メチル)]

graft-copoly [butadiene/ (styrene ;

methyl methacrylate)]

$$
\begin{aligned}
& \text { ポリブタジエン-graft-(ポリスチレン； } \\
& \text { ポリメタクリル酸メチル) } \\
& \text { polybutadiene-graft-(polystyrene； } \\
& \text { poly(methyl methacrylate)] }
\end{aligned}
$$

規則 A.1.5 末端基は接頭辞 $\alpha$ および のをつけてコ ポリマーの主名称の前で指定し，他方，ブロックの間 の接合単位は接頭辞 $\mu$ をつけて, コポリマーの主名 称の後に指定する，ある一種の接合単位が 2 回以上構 造中に現われる場合には，適切な倍数接頭辞（ビス， トリスなど）を用いる，構造中に 2 種以上の接合単位 が現われる場合には，それらを $\mu_{1} ， \mu_{2}$ などで指示す る。

例:

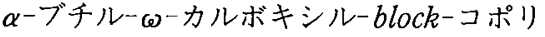

$$
\begin{aligned}
& \text { （スチレン/ブタジエン） } \\
& \alpha \text {-butyl- } \omega \text {-carboxyl-block-copoly } \\
& \text { (styrene/butadiene) } \\
& \alpha \text {-ブチルーツーカルボキシルーポリスチレ } \\
& \text { ンーblock-ポリブタジエン } \\
& \alpha \text {-butyl- } \omega \text {-carboxyl-polystyrene- } \\
& \text { block-polybutadiene. }
\end{aligned}
$$

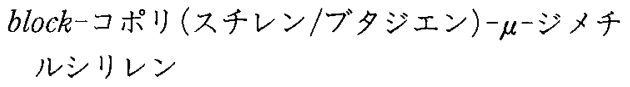

block-copoly (styrene/butadiene) $-\mu$ dimethylsilylene

ポリスチレンーblock-ジメチルシリレンblock-ポリブタジエン

polystyrene-block-dimethylsilyleneblock-polybutadiene

block-コポリ(スチレン/ブタジエン/スチレン)-

block-copoly (styrene/butadiene/styrene)-bis ( $\mu$-dimethylsilylene)

ポリスチレンーblock-ジメチルシリレンー block-ポリブタジエン-block-ジメチ ルシリレンーblock-ポリスチレン polystyrene-block-dimethylsilyleneblock-polybutadiene-blockdimethylsilylene-blockpolystyrene graft-コポリ(ブタジエン/スチレン)ーポリキス ( $\mu$-メチルシラントリイル) graft-copoly (butadiene/styrene)-polykis $\left(\mu^{-}\right.$ 
methylsilanetriyl)

規則 A.1.6 質量分率, モル分率, モル質量, 相対分 子質量, 重合度に関する指定は主文 8 節の規則の場合 と同様に取り扱う。

\section{A.2 複雑なコポリマーへの適用}

この命名法はある程度複雑なコポリマーへも拡張で きる、三，三このような場合について，諸規則と例を 以下に示す，複雑な構造に対しては一般に，本報告の 主文中に示された命名法の体系の方が望ましいことが 分かろう.

規則 A.2 グラフトコポリマーまたはブロックコポ リマーに成分としてそれ自身がコポリマーであるブロ ックが含まれる場合には，そのブロックは， $\mathrm{co}(\mathrm{B} / \mathrm{C})$

と命名され，必要があれば分類用接頭辞をつける(規 則 A.1.2 を参照).

例 :

$$
\begin{aligned}
& \text { block-コポリ（stat-co(スチレン/ブタジエ } \\
& \text { ン)/スチレン/ブタジエン」 } \\
& \text { block-copoly[stat-co(styrene/butadiene)/ } \\
& \text { styrene/butadiene) } \\
& \text { ポリ(スチレン-stat-ブタジエン)-block- } \\
& \text { ポリスチレン-block-ポリブタジエン } \\
& \text { poly(styrene-stat-butadiene)-block- } \\
& \text { polystyrene-block-polybutadiene }
\end{aligned}
$$

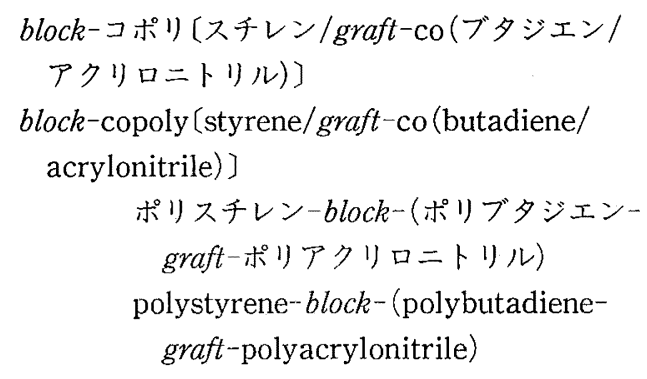

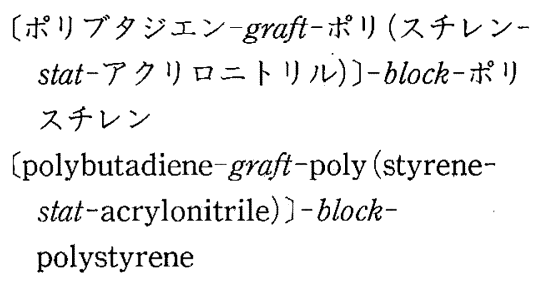

\section{A.3 重縮合または関連する重合で得られるポリマー への適用}

主文の原理および本補遺の諸規則が重縮合または関 連する重合により得られるポリマーへ適用できる。

別法による名称の例：

コポリ（6-アミノヘキサン酸/7-アミノヘプタン酸）

copoly (6-aminohexanoic acid/7-aminoheptanoic acid

alt-コポリ (エチレングリコール/テレフタル酸)

alt-copoly (ethylene glycol/terephthalic acid) alt-コポリ〔エチレングリコール/(テレフタル酸；

イソフタル酸)]

alt-copoly (ethylene glycol/(terephthalic acid : isophthalic acid)]

\section{参考文献}

1) Nomenclature of Regular Single-Strand Organic Polymers (1975), Pure Appl. Chem., 48, 373 (1976)

2) Nomenclature for Regular Single-Strand and Quasi Single-Strand Inorganic and Coordination Polymers, Pure Appl. Chem., 53, 2283 (1981)

3) Abbreviations and Symbols for Nucleic Acids, Polynucleotides, and their Constituents, Pure Appl. Chem., 40, 277 (1974)

4) Report on Nomenclature in the Field of Macromolecules, J. Polym. Sci., 8, 257 (1952)

5) Basic Definitions of Terms Relating to Polymers (1974), Pure Appl. Chem., 40, 479 (1974)

6) G.E. Ham in Encyclopedia of Polymer Science and Technology, H.F. Mark, N.G. Gaylord, and N.M. Bikales (Editors), Wiley-Intersciense, New York, 4, 165 (1966)

7) H.J. Harwood and W.M. Ritchey, J. Polym. Sci., Polym. Lett. Ed., 2, 601 (1964)

8) H.J. Harwood, Rubber Chem. Technol., 55, 769 (1982) 